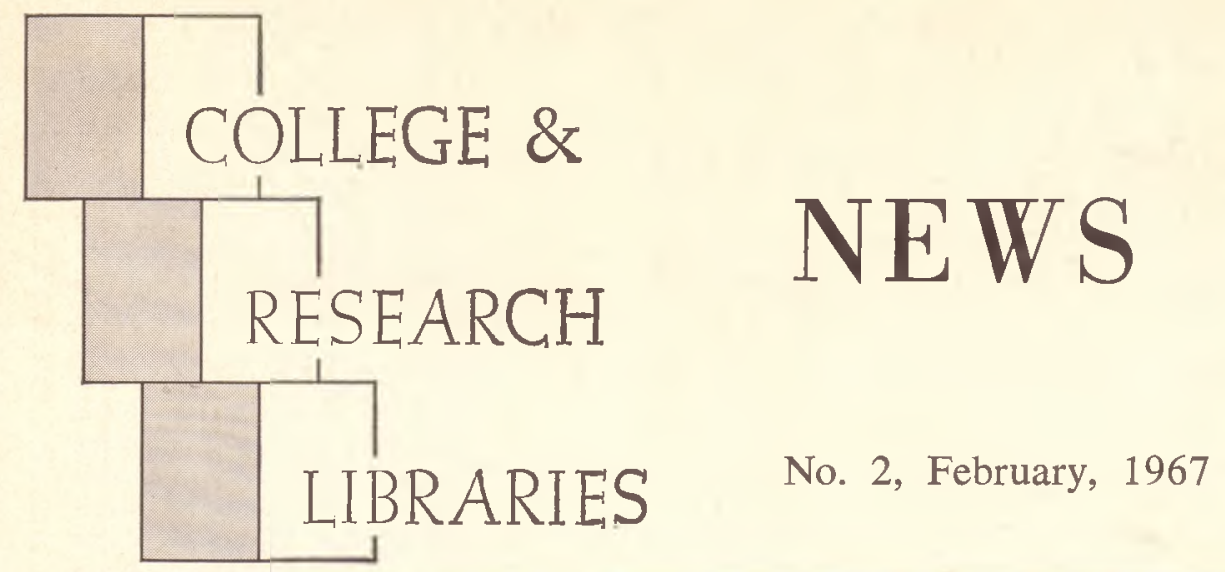

ACRL News Issue (B) of College \& Research Libraries, Vol. 28, No. 1

\title{
Higher Education Act of 1965
}

TITLE II A

The "Policies and Procedures Manual" for Title II A of the Higher Education Act of 1965 will be mailed shortly to all academic institutions. Two copies of the manual and application forms will be sent to the president of each institution. For information purposes, one copy of the manual also will be sent to the head librarian. The manual contains policies and procedures relating to the college library resources program. It includes information regarding basic, supplemental, and special purpose grants; the uses for which these grants are authorized; institutional eligibility; the permissible number and duration of grants; required institutional commitments; approval and funding level of applications; application procedures; award procedures; grantee accounting, record maintenance, and reporting procedures.

If the president of an academic institution does not receive the forms by February 28, please contact: Mr. Ray M. Fry, Director, Division of Library Services and Educational Facilities, U.S. Office of Education, Washington, D.C. 20202.

In completing the applications please note the following:

1. Amendment to the Maintenance-of-Effort Requirements under Title II A, Higher Education Act of 1965, Section 202 (a) and (b), 203 (a) (1).
In order to meet the maintenance-of-effort requirements for basic and supplemental grants, the applicant institution will expend (from non-federal funds) during the fiscal year for which the grant is requested for allowable library purposes an amount at least equal to the average annual amount it expended (from such funds) for allowable library purposes during the two-year period ending June 30,1965 , or during the two fiscal years preceding the fiscal year for which the grant is requested, whichever is the lesser; and also the applicant institution will expend (from non-federal funds) during the fiscal year for which the grant is requested for allowable library materials an amount at least equal to the average annual amount it expended (from such funds) for allowable library materials during the two-year period ending June 30, 1965 , or during the two fiscal years preceding the fiscal year for which the grant is requested, whichever is the lesser.

This change applies to basic and supplemental grants but does not apply to special purpose grants, when only "the two-year period ending June 30,1965 " is used for expenditures.

\section{Matching Funds.}

a. Basic Grants: In order to meet matching requirements the applicant institution will expend (from non-federal funds) dur- 
ing the fiscal year for which the grant is requested, an amount equal to not less than the amount of the grant (Sec. 202 (a) (2) of the Act).

The application form will indicate where to include the matching funds.

b. Supplemental Grants: No matching requirements (Sec. 203 (a) (1) of the Act).

c. Special Purpose Grants: In order to meet the matching requirements, the applicant institution will expend (from nonfederal funds) during the fiscal year for which the grant is requested for the same purpose for which the grant was awarded (library materials) an amount (from such funds) equal to not less than $33 / 3$ per cent of the amount of such grant (Sec. 204 (b) (1) of the Act).

The same matching funds cannot be used twice.

\section{Supplemental Grants.}

a. In order to receive supplemental grants, the applicant institution must apply for and be eligible to receive a basic grant in excess of $\$ 1,500$ during the same year of application.

b. Be careful to read the evaluation information properly. The footnote provided in the manual for total volumes is important. For example, using the percentages, the junior colleges having up to 1,000 students and the following number of volumes in its collection would receive these scores, using 20,000 volumes as a basis:
(a) 5,000 volumes or less
(b) 5,001 to 10,000 volumes
(c) 10,001 to 15,000 volumes
(d) 15,001 volumes or more

\section{4}
3
2

SCORE

These figures would be higher as the student body increases.

\section{Special Purpose Grants.}

a. There is no limit in the amount requested for special purpose grants.

b. In order to apply for a Type C grant, the applicant institution must apply as a member of a combination of institutions and not in the name of the combination, since grants can be awarded only to those institutions of higher education which grant degrees.

The date of notification of the award of grants will be published in a later issue of "CRL News."

(Continued on page 40)

\section{JUNIOR MEMBERS AND ACRL}

One junior member of ALA and ACRL will be appointed to serve on a number of ACRL committees, beginning in July 1967 , as a result of action taken by the ACRL Board of Directors at their Midwinter meeting.

The following statement was approved: It is recommended to the ACRL Board that a program of Intern Committee Membership be established on an experimental basis by authorizing the president-elect to appoint one extra junior member of the ACRL to standing committees for a one-year term, the candidates to be chosen if desired from a panel of nominees established by the president of the Junior Members Round Table. The Executive Secretary of the ACRL is likewise authorized to negotiate the necessary arrangements with the JMRT.

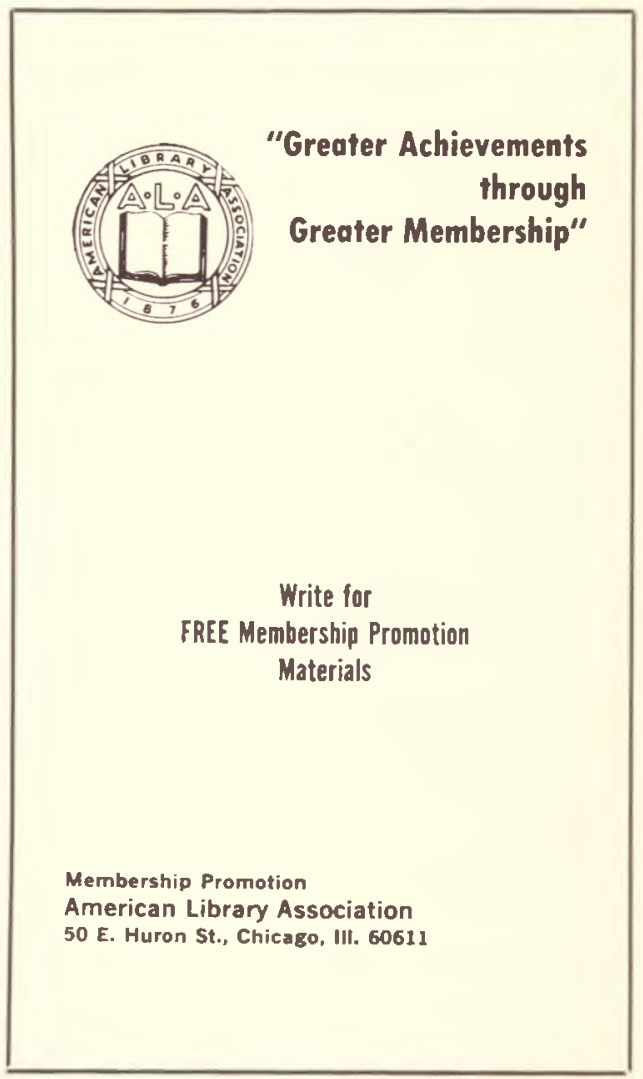




\section{Q. Who is Taylor-Carlisle? A. Taylor-Carlisle has been book- seller to libraries in the academ- ic and scientific communities for over 20 years.}

Q. What is Taylor-Carlisle?

A. Taylor-Carlisle is an organization designed for service -the fast, efficient service such libraries must have.

Q. How does Taylor-Carlisle operate?

A. Taylor-Carlisle, with its experienced personnel, tremendous inventory, and proximity to major publishers, is equipped to fill your orders quickly and efficiently.

Q. How about prices? Discounts?

A. Our terms are particularly advantageous to libraries in the academic world. Write to us for complete details.

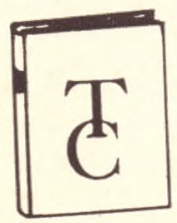

Please address: Mr. A. Fagan

Taylor-Carlisle Books

115 East 23rd Street

New York, N.Y. 10010

Tel.: (212) 674-7788 
March studying developmental book activity in East Asia for the AID.

Chai K. Kim has joined the staff of State University College at Geneseo, N.Y., as an assistant librarian.

Mrs. Donothy KNiGHT is a new member of the catalog staff, in Ablah library, Wichita State University (Kans.).

Named to a new position, in the library at California State Polytechnic College, Pomona, Lloyd A. Kramer is chief, readers' services division of the library.

WALTHER LIEBENow has been appointed assistant professor and chief circulation librarian, University of Minnesota library, Jan. 1.

William Mathews has been named assistant director of Project TIP, at MIT. In his new position, Mr. Mathews will have over-all responsibility as assistant director of Project TIP, as well as the specific task of designing and supervising the transition from present circumstances to the new generation of computers a year or so from now.

JANET NeESE was named an assistant librarian in State University College at Geneseo, N.Y.

Daniel J. Reed has been appointed deputy director of the staff of the National Advisory Commission on Libraries.

ROBERT RAYMOND is now head of the serials department, University of Nevada library.

SaM Schiag has joined the reference staff of Ablah library, Wichita State University (Kans.).

Mrs. Blanche Small recently joined the staff of Ablah library, Wichita State University (Kans.) as a cataloger.

Marvin E. SMITH has been named head, acquisitions department, California State Polytechnic College library.

Wilbur J. Stewart joined the staff of Oakland University, Rochester, Mich., as acquisitions librarian, on Jan. 1.

C. Walter Stone, director of libraries at the University of Pittsburgh, will spend part of January and February in Thailand participating in a study of developmental book activities in East Asia for the AID.

Noreen Sunderland has just been appointed librarian of the Desert Research Institute, University of Nevada.

RICHARD W. VIERICH has been named chief, technical services division of the California State Polytechnic College library.

Mrs. DarleEn Williams is assistant reference librarian, University of Nevada.

\section{HIGHER EDUCATION}

(Continued from page 26)

Any question regarding the completion of the application should be directed to the Division of Library Services and Educational Facilities, area code 202, 962-7715. =
ARE YOU FAMILIAR WITH THESE 18 TITLES?

"The ALA and You"

"Fourteen Divisions"

"Information for Institutional Members"

"Special Members"

"Key to Success"

"Meet the Challenge"

"You and Your Library"

"Choose ACRL"

"Keep in Touch"

"Exchange Ideas"

"Grow with AHIL"

"Refer Now"

"Check Your Strategy"

"It's Your Move"

"State Your Case"

"Act Now"

"Improve Library Education"

"Resources for You"

For free copies, write:

Membership Promotion

American Library Association

50 E. Huron St., Chicago, Ill. 60611 